\title{
MEMBANGUN INTENSI BERWIRAUSAHA MELALUI ADVERSITY QUOTIENT, SELF EFFICACY, DAN NEED FOR ACHIEVEMENT
}

\author{
Agung Wahyu Handaru ${ }^{1}$, Widya Parimita ${ }^{1}$, Inka Winarni Mufdhalifah ${ }^{1}$ \\ ${ }^{1}$ Fakultas Ekonomi Universitas Negeri Jakarta \\ Jalan Rawamangun Muka, Jakarta Timur 13220, Indonesia \\ *Penulis Korespondensi; Email: agung_1178@yahoo.com
}

\begin{abstract}
Abstrak
Penelitian ini berhasil mengidentifikasi kondisi terkini mengenai intensi berwirausaha di kalangan mahasiswa. Temuan dari pengujian regresi linier pada 102 mahasiswa yang dijadikan sampel penelitian adalah tingkat adversity quotient dapat mempengaruhi intensi berwirausaha mahasiswa. Temuan kedua, tingkat self-efficacy juga dapat mempengaruhi intensi berwirausaha mahasiswa. Temuan ketiga, besarnya need for achievement yang dimiliki mahasiswa juga mempengaruhi niat mereka untuk menjadi pengusaha. Temuan terakhir dari penelitian ini adalah intensi berwirausaha mahasiswa secara simultan dipengaruhi oleh adversity quotient, self-efficacy, dan need for achievement dengan besaran 46,2\%.
\end{abstract}

Kata kunci: Entrepreneurial intention, adversity quotient, self efficacy, need for achievement

\begin{abstract}
This study has identified the recent condition of entrepreneurial intention among one hundred and two students at fashion design school in Jakarta. Result of linier regression test showed that students' adversity quotient can shape their entrepreneurial intention. Second, students' self-efficacy is also shaping their entrepreneurial intention, and third, students' need for achievement contributes in building their entrepreneurial intention. Another finding showed that students' adversity quotient, self-efficacy, and need for achievement altogether can shape students' entrepreneurial intention with the cumulative of $46.2 \%$.
\end{abstract}

Keywords: Entrepreneurial intention, adversity quotient, self efficacy, need for achievement

\section{Pendahuluan}

Topik mengenai kewirausahaan selalu menarik untuk dikaji karena sifatnya yang dinamis dan terkait dengan banyak faktor seperti etnis (Constantin, Goschin, \& Dragusin, 2008; Bogan \& Darity, 2008; Maysami \& Ziemnowicz, 2007; Scheers, 2010; Handaru, Parimita, \& Subekti, 2013), tingkat pendidikan (Antoncic, Scarlat, \& Erzetic, 2005; Kalyani \& Kumar, 2011; Muofhe \& Du Toit, 2011; Raposo \& Paco, 2011), gender (Handaru, Waspodo, \& Carolina, 2013; Fuad \& Bohari, 2011) serta motivasi individu (Zaki, Fadzely \& Ahmed, 2006). Kajian mengenai kewirausahaan pada umumnya dikaitkan dengan permasalahan minimnya minat dan keberanian seseorang untuk mendirikan bisnis yang benar-benar baru (Linan, 2008; Linan \& Santos, 2007). Para peneliti di berbagai belahan dunia secara aktif mencoba mencari jawaban mengapa minat seseorang untuk menjadi pengusaha cenderung rendah. Sebagian dari hasil penelitian tersebut menyebutkan bahwa terdapat beberapa faktor yang berpengaruh terhadap tinggi dan rendahnya intensi berwirausaha seperti tingkat daya tahan terhadap tekanan atau adversity quotient (Srimulyani, 2013).

Penelitian lain yang dilakukan oleh Hmieleski dan Baron (2008), Gerhardt dan Kickul (2007), Flavius (2010), serta Handaru, Parimita, Achmad, dan Nandiswara (2014) secara konsisten mengungkapkan bahwa faktor keyakinan atas kemampuan diri sendiri atau self-efficacy berkontribusi terhadap intensi seseorang untuk membuka bisnis baru. Faktor lain yang juga banyak dikaji oleh peneliti terkait dengan minat berwirausaha adalah need for achievement atau kebutuhan seseorang akan prestasi. Dalam banyak penelitian, besarnya need for achievement juga berpengaruh terhadap tinggi dan rendahnya minat seseorang untuk berbisnis (Zaki et al., 2006; Ismail, Khalid, Othman, Jusoff, Mohammed, \& Shekh, 2009; Fuad \& Bohari, 2011; Rahman, 2011; Setyawan, 2009).

Masalah mengenai rendahnya minat membuka bisnis baru juga dialami oleh sebagian mahasiswa di Program Tata Busana Universitas Negeri Jakarta. Pada tataran ideal, program ini berupaya untuk menghasilkan lulusan yang mampu berkarir dalam dunia fashion design terutama sebagai perancang busana. 
Namun demikian dari hasil observasi awal di kalangan mahasiswa ditemukan fakta bahwa hanya $22 \%$ dari mereka yang berniat dan ingin membuka bisnis sendiri di bidang fashion design. Sisanya lebih memilih bekerja sebagai guru atau karyawan saja.

Persentase pemilihan karir mahasiswa tata busana setelah lulus

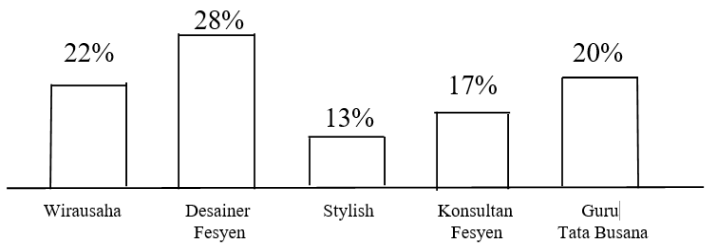

Gambar 1. Pilihan Karir Mahasiswa

Dari ilustrasi pada Gambar 1 dapat disimpulkan bahwa minat mahasiswa tata busana untuk mendirikan bisnis baru memang relatif rendah. Kondisi tersebut diduga disebabkan oleh beberapa hal yaitu pertama tingkat adversity quotient mahasiswa yang rendah. Daya tahan terhadap tekanan dalam diri mahasiswa tidak cukup terlatih karena berbagai hal. Salah satunya adalah karena kondisi lingkungan sosial mahasiswa di perkotaan yang relatif lebih nyaman/mudah dibandingkan dengan beberapa dekade yang lalu serta budaya serba instan seperti sekarang ini. Penyebab kedua adalah tingkat self-efficacy mahasiswa yang tidak optimal.

Keyakinan diri mahasiswa akan kemampuannya untuk dapat melakukan tugas dengan baik cenderung rendah karena mahasiswa merasa pengetahuan dan kemampuannya dalam fashion design masih kurang. Salah satu penyebabnya adalah berkaitan dengan kurikulum yang belum mengoptimalkan praktikum desain/perancangan busana untuk para mahasiswa. Penyebab berikutnya yang diduga menjadi penyebab rendahnya minat berwirausaha mahasiswa adalah need for achievement yang cenderung biasa saja. Mahasiswa memandang profesi sebagai perancang busana bukanlah profesi yang hebat, sehingga mereka tidak terdorong untuk berprestasi dalam bidang tersebut.

Dari penjelasan di atas dapat disusun beberapa rumusan masalah dalam penelitian ini, yaitu bagaimana sebenarnya gambaran tentang entrepreneurial intention, adversity quotient, self-efficacy, dan juga need for achievement mahasiswa? Rumusan masalah berikutnya adalah apakah secara parsial dan simultan $a d-$ versity quotient, self-efficacy, dan juga need for achievement mahasiswa berpengaruh terhadap rendahnya entrepreneurial intention mereka? Rumusan masalah terakhir adalah berapa besar kontribusi yang dihasilkan oleh adversity quotient, self-efficacy, dan need for achievement dalam membentuk entrepreneurial intention?

Berdasarkan rumusan masalah di atas, tujuan penelitian ini tidak lain adalah untuk mengetahui adakah pengaruh adversity quotient, self-efficacy, dan need for achievement terhadap entrepreneurial intention mahasiswa baik secara parsial maupun simultan, sehingga pada akhirnya dapat dijadikan acuan untuk menyusun saran perbaikan terhadap rendahnya minat berwirausaha di kalangan mahasiswa program tata busana. Tujuan penelitian selanjutnya adalah untuk mengetahui berapa besar kontribusi adversity quotient, self-efficacy, dan need for achievement dalam membentuk entrepreneurial intention mahasiswa

\section{Intensi Berwirausaha}

Kecenderungan seseorang untuk melakukan perilaku tertentu disebut dengan intensi. Oleh karena itu intensi merupakan suatu komponen yang ada pada diri individu yang mengacu pada keinginan untuk melakukan tingkah laku tertentu. Menurut Wijaya (2007) intensi adalah komponen dalam diri individu yang mengacu pada keinginan untuk melakukan tingkah tertentu. Hal senada juga diungkapkan oleh Sukmana (2008) yang mengatakan bahwa intensi menggambarkan keinginan untuk melakukan sesuatu. Pendapat lainnya dikemukakan oleh Handaru et al. (2014) yang menjelaskan bahwa intensi adalah hal-hal yang diasumsikan dapat menjelaskan faktor-faktor motivasi serta berdampak kuat pada tingkah laku. Sejalan dengan pendapat tersebut, Vemmy (2013) menyebutkan bahwa intensi adalah bagian dari diri individu yang dilatarbelakangi oleh motivasi seseorang untuk bertindak. Pada kajian lain, Srimulyani (2013) menegaskan bahwa intensi merupakan motivasi seseorang yang secara sadar memutuskan untuk mengerahkan usaha untuk melakukan suatu perilaku.

\section{Dimensi Intensi Berwirausaha}

Dalam tulisannya, Vemmy (2013) menyebutkan bahwa intensi berwirausaha seseorang dapat ditinjau dari empat dimensi, yaitu desires, preferences, plans dan behavior expectancies. Desires adalah sesuatu dalam diri seseorang yang berupa keinginan atau hasrat yang tinggi untuk memulai suatu usaha. Preferences adalah sesuatu dalam diri seseorang yang menunjukkan bahwa memiliki usaha atau bisnis yang mandiri adalah suatu kebutuhan yang harus dicapai. Plans merujuk pada harapan dan rencana yang ada dalam diri seseorang untuk memulai suatu usaha di masa yang akan datang. Behavior expectancies adalah tinjauan atas suatu kemungkinan untuk berwirausaha dengan diikuti oleh target dimulainya sebuah usaha bisnis. 
Dalam kajian yang lain, Linan dan Chen (2006) mengungkapkan bahwa untuk mengukur intensi berwirausaha seseorang dapat menggunakan pendekatan pernyataan tertentu seperti yaitu: desire (I want to), self-prediction (how likely it is) dan behavioral intention (I intend to) Dengan demikian dapat disimpulkan bahwa intensi berwirausaha diukur melalui seberapa besar keinginan individu untuk memulai bisnis yang baru. Prediksi individu mengacu pada seberapa besar kemungkinan untuk memulai bisnis tersebut dapat dilakukan dan gambaran tentang perilaku bisnis yang tampak dari individu.

\section{Adversity Quotient}

Kata adversity berasal dari bahasa Inggris yang berarti kegagalan atau kemalangan (Alfiyah, 2012). Adversity sendiri bila diartikan dalam bahasa Indonesia bermakna kesulitan atau kemalangan dan dapat diartikan sebagai suatu kondisi ketidakbahagiaan, kesulitan, atau ketidakberuntungan. Istilah adversity dalam kajian psikologi didefinisikan sebagai tantangan dalam kehidupan (Alfiyah, 2012). Definisi adversity quotient menurut Zaki et al. (2006) merupakan suatu penilaian yang mengukur bagaimana respon seseorang dalam menghadapai masalah untuk dapat diberdayakan menjadi peluang. Menurut Wijaya (2007), adversity quotient adalah kemampuan berpikir, mengelola dan mengarahkan tindakan yang membentuk pola-pola tanggapan kognitif dan perilaku atas stimulus peristiwa-peristiwa dalam kehidupan yang berupa tantangan atau kesulitan. Dari beberapa penjelasan di atas, adversity quotient dapat digambarkan sebagai kemampuan seseorang dalam merespon hambatan dan kesulitan melalui kecerdasannya dalam mengelola dan bertindak, dan selanjutnya mampu memanfaatkannya menjadi peluang.

\section{Dimensi Adversity Quotient}

Kajian Zaki et al. (2006) menjelaskan bahwa adversity quotient terdiri atas empat dimensi yang meliputi kendali/control (C), daya tahan/endurance (E), jangkauan/reach $(\mathrm{R})$, kepemilikan/origin, dan ownership (O2). Mereka kemudian secara rinci menjabarkan bahwa control berkaitan dengan seberapa besar orang merasa mampu mengendalikan kesulitan-kesulitan yang dihadapinya dan sejauh mana individu merasakan bahwa kendali tersebut ikut berperan dalam peristiwa yang menimbulkan kesulitan. Daya tahan (endurance) merupakan persepsi seseorang akan lama atau tidaknya kesulitan akan berlangsung. Adapun jangkauan (reach) merupakan bagian dari adversity quotient yang menjelaskan tentang sejauh mana ke- sulitan akan dapat menjangkau atau mempengaruhi bagian lain dari seseorang. Reach juga berarti sejauh mana kesulitan yang dialami akan bisa mempengaruhi aspek lain dari kehidupan seseorang. Kepemilikan/origin dan ownership $(\mathrm{O} 2)$ merupakan awal mula dan pengakuan yang menjelaskan siapa atau apa yang menimbulkan kesulitan bagi seseorang. Aspek ini juga dapat diartikan sejauh mana seorang individu menganggap dirinya sendiri sebagai penyebab munculnya kesulitan.

Terkait intensi berwirausaha, adversity quotient menentukan kemampuan seseorang untuk bertahan dan menghadapi kesulitan, serta meraih kesuksesan (Alfiyah, 2012). Masih menurut Alfiyah (2012) seorang individu yang memiliki adversity quotient tinggi diduga akan lebih mudah menjalani profesi sebagai seorang wirausahawan karena memiliki kemampuan untuk mengubah hambatan menjadi peluang. Dalam tulisan lain, individu yang memiliki kecerdasan menghadapi rintangan akan memiliki kemampuan untuk menangkap peluang usaha karena memiliki kemampuan menanggung risiko, berorientasi pada peluang/inisiatif, memiliki kreativitas, kemandirian, dan kemampuan untuk mengerahkan sumber daya (Rahardjo \& Darmawan, 2014). Berdasarkan uraian di atas dapat dikatakan bahwa adversity quotient adalah kemampuan seseorang dalam merespon hambatan dan kesulitan melalui kecerdasannya dalam mengelola sumberdaya dan melakukan tindakan tertentu.

\section{Self-Efficacy}

Kajian Hmieleski dan Baron (2008) mengungkapkan bahwa self-efficacy adalah tingkat kepercayaan diri seseorang dalam mengerjakan tugas atau pekerjaan tertentu dengan baik. Self-efficacy juga dapat menjadi faktor pendorong bagi seseorang dan dapat dipakai untuk memprediksi perilaku tertentu (Hmieleski \& Baron, 2008). Self-efficacy sering dikaitkan dengan keputusan berkarir seseorang, karena untuk memilih sebuah pekerjaan seseorang cenderung memikirkan kemampuan dirinya untuk melakukan pekerjaan tersebut.

\section{Pengukuran Self-Efficacy}

Self-efficacy menjadi faktor penting yang dapat mempengaruhi tindakan atau cara bekerja seseorang (Flavius, 2010). Tingkat self-efficacy juga mencerminkan tinggi rendahnya komitmen seseorang untuk meraih sesuatu yang ingin dicapainya. Dimensi selfefficacy secara umum terdiri atas magnitude, strength, dan generality (Flavius, 2010; Gerhardt \& Kickul, 
2007). Aspek magnitude berkaitan dengan penilaian seseorang akan tingkat kesulitan dari sebuah pekerjaan yang harus dihadapinya. Aspek strength berhubungan dengan tingkat kepercayaan diri seseorang untuk mampu menyelesaikan sebuah pekerjaan dengan baik. Aspek generality adalah keyakinan seseorang untuk dapat menyelesaikan tugas lain secara umum yang memiliki kemiripan.

Terkait dengan intensi tersebut, Hmieleski dan Baron (2008) berpendapat bahwa self-efficacy dapat mendorong kinerja seseorang dalam berbagai bidang termasuk minat berwirausaha. Lebih jauh, Flavius (2010) mengungkapkan bahwa tingkat self-efficacy seseorang dapat menggambarkan proses pemilihan dan penyesuaian diri terhadap pilihan karir dalam hidupnya. Oleh karena itu, dapat disimpulkan bahwa semakin tinggi tingkat self-efficacy seseorang terhadap dunia bisnis, akan semakin kuat intensi berwirausahanya. Dengan kata lain, ketika seseorang akan membuka bisnis baru, diperlukan keyakinan diri (selfefficacy) bahwa dirinya mampu menjalani seluruh aktivitas bisnis agar usahanya dapat berhasil (Handaru et al., 2013).

Senada dengan pendapat di atas, Flavius (2010) mengemukakan bahwa tingkat self-efficacy seeorang akan mempengaruhi pandangannya dalam melihat hasil positif yang mungkin terjadi pada usaha yang baru dan mengejar tujuan tersebut dengan lebih bersemangat. Dengan demikian, tingkat self-efficacy menjadi faktor penting bagi seseorang ketika hendak memutuskan untuk menjadi pengusaha sebagai profesinya.

\section{Need for Achievement}

Istilah need for achievement pertama kali dipopulerkan oleh Mc.Clelland dengan sebutan $n$-ach yang merupakan singkatan dari need for achievement (Handaru et al., 2013). Menurut Srimulyani (2013) motivasi berprestasi dapat diartikan sebagai usaha untuk mencapai kesuksesan atau usaha untuk mencapai keberhasilan dalam sebuah persaingan dengan suatu ukuran tertentu. Dalam tulisan lain, motivasi berprestasi yang ada dalam diri seseorang akan manjadi pendorong untuk dapat menguasai, memanipulasi atau mengatur lingkungan sosial maupun fisik di sekitarnya (Kalyani \& Kumar, 2011). Dalam tulisannya, Setyawan (2009) berpendapat bahwa tingkat need for achievement akan membuat seseorang mampu mengatasi segala rintangan, menghasilkan kualitas kerja yang tinggi, serta dapat bersaing untuk menjadi yang terbaik. Pendapat senada dikemukakan oleh Zaki et al. (2006) yang menyebutkan bahwa motivasi berprestasi dapat diartikan sebagai suatu dorongan dalam diri seseorang untuk melakukan atau mengerjakan suatu kegiatan atau tugas dengan sebaik-baiknya. Dalam tulisannya, Setyawan (2009). Menjelaskan beberapa aspek yang dapat digunakan untuk mengukur tingkat need for achievement seseorang yaitu aspek kebutuhan akan pencapaian, kesediaan untuk mengambil tanggung jawab, memiliki rasa takut akan kegagalan, kemampuannya dalam mengatasi hambatan atau kendala, dan yang terakhir kesediaan untuk menerima kritik dan masukan dari orang lain. Masih terkait dengan pendapat di atas, Rahman (2011) juga menyebutkan beberapa aspek yang berkaitan dengan tingkat need for achievement seseorang yaitu bersedia bertanggung jawab, teliti dan mempertimbangkan risiko, mengharapkan adanya umpan balik, bersikap kreatif dan inovatif, memperhatikan waktu penyelesaian tugas, serta memiliki keinginan yang kuat untuk menjadi yang terbaik.

\section{Kerangka Pemikiran}

Untuk membangun minat berwirausaha yang tinggi, seorang individu perlu memiliki adversity quotient atau daya tahan mental terhadap kesulitan yang mantap dan solid (Alfiyah, 2012; Wijaya, 2007). Pentingnya tingkat adversity quotient yang tinggi ketika memulai bisnis adalah berdasarkan fakta bahwa banyak sekali pengusaha baru yang menemui kendala dan kesulitan dalam aktivitas bisnisnya. Kondisi ini juga diperburuk dengan kondisi lingkungan bisnis saat ini yang penuh ketidakpastian. Untuk mengatasi hal tersebut, sangat diperlukan ketahanan mental yang tinggi dari calon entrepreneur. Berdasarkan gambaran tersebut dapat dikatakan bahwa adversity quotient akan berpengaruh positif terhadap minat berwirausaha seseorang (Rahardjo \& Darmawan, 2014).

Faktor lain yang berpengaruh terhadap minat berwirausaha seseorang adalah self-efficacy atau tingkat keyakinan diri untuk dapat mengerjakan tugas dan pekerjaan dengan baik. Seseorang dengan self-efficacy yang tinggi di bidang bisnis akan mendorong dirinya untuk lebih berani memulai sebuah bisnis yang baru. Dengan demikian self-efficacy dalam bidang bisnis yang dimiliki seseorang akan berpengaruh positif terhadap minatnya untuk membuka usaha baru (Hmieleski \& Baron, 2008; Handaru et al., 2013).

Faktor ketiga yang juga terkait dengan intensi berwirausaha seseorang adalah tingkat need for achievement dalam dirinya. Seseorang yang memiliki hasrat dan keinginan yang kuat untuk berkinerja tinggi dalam bisnis akan mencurahkan energi dan upaya 
yang keras untuk memulai bisnis tersebut (Flavius, 2010). Dengan kata lain need for achievement memiliki kontribusi positif dalam membangun minat berwirausaha seorang individu (Rahman, 2011). Berdasarkan kerangka pemikiran di atas, maka model penelitian seperti terlihat dalam Gambar 2.

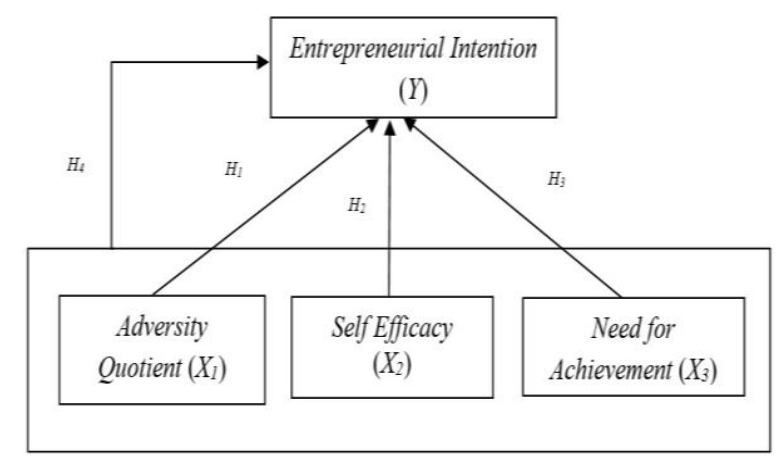

\section{Gambar 2. Model Penelitian}

Berdasarkan model penelitian pada Gambar 2, hipotesis yang diajukan dalam penelitian ini adalah:

$H_{1}$ : Tingkat adversity quotient berpengaruh positif terhadap Entrepreneurial Intention (intensi berwirausaha) mahasiswa.

$\mathrm{H}_{2}$ : Tingkat self-efficacy berpengaruh positif terhadap Entrepreneurial Intention (intensi berwirausaha) mahasiswa.

$H_{3:}$ Besarnya need for achievement berpengaruh positif terhadap Entrepreneurial Intention (intensi berwirausaha) mahasiswa.

$H_{4:}$ Secara simultan adversity quotient, self-efficacy, dan need for achievement berpengaruh positif terhadap Entrepreneurial Intention (intensi berwirausaha) mahasiswa.

\section{Metode Penelitian}

Penelitian ini menggunakan metode penelitian deskriptif dan eksplanatori. Penelitian deskriptif merupakan penelitian terhadap masalah-masalah berupa fakta-fakta saat ini dari suatu populasi. Tujuan penelitian deskriptif adalah untuk menguji hipotesis atau menjawab pertanyaan yang berkaitan dengan opini (individu, kelompok atau organisasional), kejadian atau prosedur. Penelitian eksplanatori berguna untuk mengetahui ada atau tidaknya pengaruh antar variabel atau untuk membuat prediksi berdasarkan korelasi antar variabel (Sugiyono, 2013).

Metode survei akan digunakan dalam penelitian ini sehingga pengumpulan data akan dilakukan menggunakan sampel. Populasi dalam penelitian ini adalah mahasiswa program studi tata busana angkatan 2010 dan 2011 yang berjumlah 137 orang. Populasi ini dipilih berdasarkan beberapa pertimbangan yaitu: pertama, pengetahuan dan keterampilan mereka di bidang kewirausahaan sudah dirasakan cukup tinggi dan kedua, mereka adalah mahasiswa tingkat akhir yang sepatutnya sudah memiliki gambaran dan keinginan untuk berkarir di bidang formal atau informal.

Dalam menentukan sampel, metode yang dipakai adalah probability sampling dengan teknik proportionate stratified random sampling. Metode ini dapat digunakan apabila populasi mempunyai anggota/ unsur yang tidak homogen dan berstrata secara proporsional (Sugiyono, 2013). Dari populasi berjumlah 137 orang, maka jumlah sampel dalam penelitian ini adalah 102 orang yang dihitung dengan menggunakan formula dari Slovin (Sugiyono, 2013). Seluruh sampel tersebut akan diminta untuk mengisi instrumen/angket yang telah disiapkan.

Angket penelitian akan diuji validitas dan reliabilitasnya untuk memastikan kualitas data yang nanti akan digunakan (Sugiyono, 2013). Skala pengukuran/ measurement scale yang digunakan dalam angket adalah skala interval 1 sampai 5, dimana skala interval menjadi syarat untuk melakukan analisis regresi (Hair, Black, Babin, Anderson, \& Tatham, 2006). Pengujian hipotesis dalam penelitian ini akan menggunakan aplikasi software SPSS. Oleh karena penelitian ini akan menggunakan analisis regresi linier berganda, maka terlebih dahulu perlu dilakukan beberapa pengujian asumsi klasik seperti uji normalitas data, linearitas, multikolinearitas dan heteroskedastisitas agar hasil uji hipotesisnya memiliki keakuratan yang tinggi (Ghozali, 2005; Kuncoro, 2009; Sugiyono, 2013).

\section{Hasil Penelitian dan Pembahasan}

\section{Uji Validitas dan Reliabilitas}

Setelah dilakukan uji validitas terhadap angket yang digunakan, hasilnya dapat Tabel 1.

Dari Tabel 1 terlihat bahwa uji validitas melalui aplikasi SPSS terhadap variabel adversity quotient, self-efficacy, need for achievement, dan intensi berwirausaha menunjukkan bahwa semua item adalah valid. Hal ini dikarenakan seluruh item pernyataan mempunyai nilai koefisien korelasi yang lebih besar dibandingkan $r_{\text {tabel }}$ (dengan $n=30$ ) yaitu 0,361 (Ghozali, 2005). Artinya seluruh item pernyataan pada angket dapat digunakan dalam penelitian.

Selanjutnya hasil uji reliabilitas angket penelitian dapat dilihat pada Tabel 2 . 
Tabel 1

Hasil Uji Validitas

\begin{tabular}{|c|c|c|c|}
\hline Item & $r_{\text {hitung }}$ & $r_{\text {tabel }}$ & Keterangan \\
\hline \multicolumn{4}{|c|}{ Adversity Quotient } \\
\hline butir 1 & 0,392 & 0,361 & Valid \\
\hline butir 2 & 0,726 & 0,361 & Valid \\
\hline butir 3 & 0,480 & 0,361 & Valid \\
\hline butir 4 & 0,679 & 0,361 & Valid \\
\hline butir 5 & 0,492 & 0,361 & Valid \\
\hline butir 6 & 0,542 & 0,361 & Valid \\
\hline butir 7 & 0,526 & 0,361 & Valid \\
\hline butir 8 & 0,728 & 0,361 & Valid \\
\hline butir 9 & 0,644 & 0,361 & Valid \\
\hline butir 10 & 0,598 & 0,361 & Valid \\
\hline \multicolumn{4}{|c|}{ Self-Efficacy } \\
\hline butir 11 & 0,423 & 0,361 & Valid \\
\hline butir 12 & 0,720 & 0,361 & Valid \\
\hline butir 13 & 0,469 & 0,361 & Valid \\
\hline butir 14 & 0,700 & 0,361 & Valid \\
\hline butir 15 & 0,468 & 0,361 & Valid \\
\hline butir 16 & 0,409 & 0,361 & Valid \\
\hline butir 17 & 0,484 & 0,361 & Valid \\
\hline butir 18 & 0,471 & 0,361 & Valid \\
\hline butir 19 & 0,705 & 0,361 & Valid \\
\hline butir 20 & 0,473 & 0,361 & Valid \\
\hline \multicolumn{4}{|c|}{ Need For Achievement } \\
\hline butir 21 & 0,746 & 0,361 & Valid \\
\hline butir 22 & 0,664 & 0,361 & Valid \\
\hline butir 23 & 0,651 & 0,361 & Valid \\
\hline butir 24 & 0,711 & 0,361 & Valid \\
\hline butir 25 & 0,750 & 0,361 & Valid \\
\hline butir 26 & 0,444 & 0,361 & Valid \\
\hline butir 27 & 0,498 & 0,361 & Valid \\
\hline butir 28 & 0,548 & 0,361 & Valid \\
\hline butir 29 & 0,608 & 0,361 & Valid \\
\hline butir 30 & 0,534 & 0,361 & Valid \\
\hline butir 31 & 0,501 & 0,361 & Valid \\
\hline \multicolumn{4}{|c|}{ Intensi Berwirausaha } \\
\hline butir 32 & 0,470 & 0,361 & Valid \\
\hline butir 33 & 0,699 & 0,361 & Valid \\
\hline butir 34 & 0,657 & 0,361 & Valid \\
\hline butir 35 & 0,708 & 0,361 & Valid \\
\hline butir 36 & 0,789 & 0,361 & Valid \\
\hline butir 37 & 0,600 & 0,361 & Valid \\
\hline butir 38 & 0,837 & 0,361 & Valid \\
\hline butir 39 & 0,613 & 0,361 & Valid \\
\hline butir 40 & 0,777 & 0,361 & Valid \\
\hline butir 41 & 0,554 & 0,361 & Valid \\
\hline butir 42 & 0,759 & 0,361 & Valid \\
\hline
\end{tabular}

Tabel 2

Hasil Uji Reliabilitas

\begin{tabular}{lll}
\hline \multicolumn{1}{c}{ Variables } & Score & Result \\
\hline Adversity Quotient & 0,752 & Reliabel \\
Self Efficacy & 0,705 & Reliabel \\
Need for Achievement & 0,825 & Reliabel \\
Entrepreneurial Intention & 0,876 & Reliabel
\end{tabular}

Hasil uji reliabiltas yang terdapat pada Tabel 2 memperlihatkan bahwa variabel adversity quotient memiliki nilai koefisien alpha 0,752, self-efficacy bernilai 0,705, need for achievement bernilai 0,825 dan Entrepreneurial Intention (intensi berwirausaha) bernilai 0,876 . Hal ini menunjukkan bahwa instrumen dari keempat dimensi tersebut dinyatakan reliabel karena nilai Cronbach's Alpha lebih besar dari 0,6 (Ghozali, 2005; Sugiyono, 2013)

\section{Analisis Deskriptif}

Setiap dimensi pada variabel adversity quotient mendapat respon jawaban dengan skor dua yang cukup banyak seperti pada dimensi control sebesar 43,46\%, dimensi origin/ownership 46,08\%, dimensi reach $42,16 \%$, dan dimensi endurance sebesar $35,95 \%$. Oleh karena itu dapat disimpulkan bahwa mayoritas responden memiliki adversity quotient yang rendah.

Hasil berikutnya adalah hanya 3,98\% dari responden yang menjawab bahwa mereka memiliki selfefficacy yang sangat tinggi. Hasil juga menunjukkan bahwa 33,03\% responden memiliki self-efficacy yang rendah, sedangkan responden yang memilliki self-efficacy cukup tinggi hanya sebesar 24,48\% dan 36,03\% menjawab tidak yakin atas self-efficacy mereka sendiri.

Untuk variabel need for achievement, hanya $1,83 \%$ dari seluruh responden yang menjawab bahwa mereka memiliki need for achievement yang sangat tinggi. Jawaban terbanyak yaitu 38,73\% adalah pada tingkat need for achievement yang rendah. Selanjutnya, jawaban dari seluruh sampel mengungkapkan bahwa hanya $5,06 \%$ dari mereka yang memiliki intensi berwirausaha sangat tinggi. Mayoritas jawaban responden adalah pada tingkat intensi yang rendah pada kisaran $34 \%$.

\section{Uji Normalitas Data}

Uji normalitas pada penelitian ini menggunakan uji Kolmogorov-Smirnov dan dikatakan normal jika nilai residual yang terdistribusi secara normal memiliki probabilitas signifikansi lebih besar dari 0,05 (Sugiyono, 2013) Hasil uji normalitas dapat dilihat pada Tabel 3.

Tabel 3

Hasil Uji Normalitas

\begin{tabular}{lccc}
\hline & Statistic & Df & Sig. \\
\hline AQ & 0,085 & 102 & 0,091 \\
SE & 0,074 & 102 & 0,195 \\
NACH & 0,079 & 102 & 0,92 \\
IB & 0,079 & 102 & 0,121 \\
\hline
\end{tabular}


Hasil uji normalitas pada Tabel 3 menunjukkan bahwa nilai signifikansi untuk variabel adversity quotient sebesar 0,091; self-efficacy sebesar 0,195; need for achievement sebesar 0,92 dan intensi berwirausaha sebesar 0,121. Jadi, variabel adversity quotient, self-efficacy, need for achievement dan intensi berwirausaha berdistribusi normal karena nilai signifikasi untuk seluruh variabel lebih besar dari 0,05 .

\section{Uji Linearitas}

Kriteria dalam uji linearitas adalah dua variabel dikatakan mempunyai hubungan yang linear bila signifikasi (linearity) kurang dari 0,05 (Sugiyono, 2013). Hasil uji linearitas dapat dilihat pada Tabel 4, Tabel 5, dan Tabel 6.

Berdasarkan Tabel 4 diketahui bahwa nilai signifikasi pada linearity adalah sebesar 0,002. Jadi, dapat disimpulkan bahwa antara variabel adversity quotient dan intensi berwirausaha memiliki hubungan yang linear. Dari Tabel 5 juga dapat dilihat bahwa antara variabel self-efficacy dan variabel intensi berwirausaha nilai signifikansi linearity adalah sebesar 0,000 sehingga dapat disimpulkan bahwa di antara kedua variabel tersebut terdapat hubungan yang linier. Dari Tabel 6 juga dapat terlihat bahwa antara variabel need for achievement dengan variabel intensi berwirausaha signifikansi linearity nya adalah sebesar 0,000 sehingga dapat disimpulkan bahwa di antara kedua variabel tersebut terdapat hubungan yang linier.

\section{Uji Multikolinearitas}

Uji multikolinearitas berguna untuk mengetahui apakah pada model regresi ditemukan adanya korelasi yang kuat antar variabel bebas (independen). Syarat yang harus dipenuhi adalah tidak adanya multikolinearitas dalam model regresi. Multikoliniearitas dapat diketahui dengan melihat nilai Variance Inflation Factor (VIF) pada model regresi. Jika besarnya VIF kurang dari 5, maka mencerminkan tidak ada

Tabel 4

Uji Linearitas Adversity Quotient Dengan Intensi Berwirausaha

\begin{tabular}{llcrrrr}
\hline \multicolumn{1}{c}{ ANOVA Table } & & & \\
\hline & & Sum of Squares & Df & Mean Square & \multicolumn{1}{c}{$F$} & Sig. \\
\hline IB * AQ Between Groups & (Combined) & 405,055 & 17 & 23,827 & 1,838 & 0,036 \\
& Linearity & 130,090 & 1 & 130,090 & 10,034 & 0,002 \\
& Deviation from Linearity & 274,966 & 16 & 17,185 & 1,326 & 0,201 \\
& Within Groups & $1.089,023$ & 84 & 12,965 & & \\
& Total & $1.494,078$ & 101 & & & \\
\hline
\end{tabular}

Tabel 5

Uji Linearitas Self Efficacy dengan Intensi Berwirausaha

\begin{tabular}{llrrrrr}
\hline & & Sum of Squares & \multicolumn{1}{c}{ Df } & Mean Square & \multicolumn{1}{c}{$F$} & Sig. \\
\hline IB * SE Between Groups & (Combined) & 715,267 & 17 & 42,075 & 4,538 & 0,000 \\
& Linearity & 599,540 & 1 & 599,540 & 64,664 & 0,000 \\
& Deviation from Linearity & 115,727 & 16 & 7,233 & 0,780 & 0,703 \\
& Within Groups & 778,811 & 84 & 9,272 & & \\
& Total & $1.494,078$ & 101 & & & \\
\hline
\end{tabular}

Tabel 6

Uji Linearitas Need for Achievement dengan Intensi Berwirausaha

\begin{tabular}{|c|c|c|c|c|c|c|}
\hline \multicolumn{7}{|c|}{ ANOVA Table } \\
\hline & & Sum of Squares & $d f$ & Mean Square & $F$ & Sig. \\
\hline \multirow[t]{5}{*}{ IB * NACH Between Groups } & (Combined) & 664,099 & 18 & 36,894 & 3,690 & 0,000 \\
\hline & Linearity & 496,999 & 1 & 496,999 & 49,701 & 0,000 \\
\hline & Deviation from Linearity & 167,100 & 17 & 9,829 & 0,983 & 0,485 \\
\hline & Within Groups & 829,980 & 83 & 10,000 & & \\
\hline & Total & $1.494,078$ & 101 & & & \\
\hline
\end{tabular}


gejala multikolinieritas (Ghozali, 2005). Hasil uji multikoliniearitas dapat dilihat pada Tabel 7.

Tabel 7

Hasil Uji Multikolinearitas

\begin{tabular}{|c|c|c|c|}
\hline \multicolumn{4}{|c|}{ Coefficients $^{a}$} \\
\hline & \multirow{2}{*}{ Model } & \multicolumn{2}{|c|}{ Collinearity Statistics } \\
\hline & & Tolerance & $V I F$ \\
\hline \multirow[t]{3}{*}{1} & AQ & 0,970 & 1,031 \\
\hline & $\mathrm{SE}$ & 0,424 & 2,360 \\
\hline & $\mathrm{NACH}$ & 0,431 & 2,320 \\
\hline
\end{tabular}

Berdasarkan hasil uji multikolinearitas pada Tabel 7, diketahui bahwa angka VIF untuk variabel $a d-$ versity quotient, self-efficacy, dan need for achievement secara berurutan adalah sebesar 1,$031 ; 2,360$; dan 2,320. Nilai $V I F$ dari seluruh variabel bebas adalah kurang dari 5 , maka di antara kedua variabel bebas tersebut tidak ditemukan adanya masalah multikolinearitas.

\section{Uji Heteroskedastisitas}

Uji heteroskedastisitas dilakukan untuk mengetahui apakah dalam sebuah model regresi terjadi ketidaksamaan varian dari residual suatu pengamatan ke pengamatan lain. Jika varian residual suatu pengamatan ke pengamatan lain tetap, disebut homoskedastisitas, sedangkan untuk varian yang berbeda disebut heteroskedastisitas. Syarat yang harus dipenuhi dalam model regresi adalah tidak adanya masalah heteroskedastisitas (Ghozali, 2005; Sugiyono, 2013). Hasil pengujian dapat dilihat pada Tabel 8.

Pengujian heteroskedastisitas yang digunakan adalah uji Spearman's Rho, yaitu mengkorelasikan nilai residual (unstandardized residual) dengan masing-masing variabel independen. Jika signifikansi kurang dari 0,05 maka terjadi masalah heteroskedastisitas (Sugiyono, 2013). Pada tabel di atas terlihat bahwa korelasi antara adversity quotient dengan unstandardized residual menghasilkan nilai signifikasi 0,684; korelasi antara self-efficacy dengan unstandardized residual menghasilkan nilai 0,892; dan korelasi antara need for achievement dengan unstandardized residual menghasilkan nilai 0,933 . Jadi, dapat disimpulkan bahwa pada model regresi tidak ditemukan adanya masalah heteroskedastisitas karena nilai signifikasi korelasi lebih besar dari 0,05.

\section{Uji Hipotesis}

Hasil uji hipotesis dalam penelitian ini dapat dilihat dalam Tabel 9.

\section{Tabel 8}

Hasil Uji Heteroskedastisitas

\begin{tabular}{|c|c|c|c|c|c|c|}
\hline \multicolumn{7}{|c|}{ Correlations } \\
\hline & & & $A Q$ & $S E$ & $\mathrm{NACH}$ & Unstandardized Residual \\
\hline \multirow[t]{12}{*}{ Spearman's rho } & $\mathrm{AQ}$ & Correlation Coefficient & 1,000 & 0,110 & 0,041 & $-0,041$ \\
\hline & & Sig. (2-tailed) & & 0,270 & 0,682 & 0,684 \\
\hline & & $N$ & 102 & 102 & 102 & 102 \\
\hline & $\overline{\mathrm{SE}}$ & Correlation Coefficient & 0,110 & 1,000 & $0,761^{\text {*** }}$ & 0,014 \\
\hline & & Sig. (2-tailed) & 0,270 & & 0,000 & 0,892 \\
\hline & & $N$ & 102 & 102 & 102 & 102 \\
\hline & $\overline{\mathrm{NACH}}$ & Correlation Coefficient & 0,041 & $0,761^{* * *}$ & 1,000 & $-0,008$ \\
\hline & & Sig. (2-tailed) & 0,682 & 0,000 & & 0,933 \\
\hline & & $N$ & 102 & 102 & 102 & 102 \\
\hline & Unstandardized & Correlation Coefficient & $-0,041$ & 0,014 & $-0,008$ & 1,000 \\
\hline & Residual & Sig. (2-tailed) & 0,684 & 0,892 & 0,933 & \\
\hline & & $N$ & 102 & 102 & 102 & 102 \\
\hline
\end{tabular}

\section{Tabel 9}

Hasil Uji Hipotesis

\begin{tabular}{llccccc}
\hline \multicolumn{7}{c}{ Coefficients $^{a}$} \\
\hline \multirow{2}{*}{ Model } & \multicolumn{4}{c}{ Unstandardized Coefficients } & \multicolumn{3}{c}{ Standardized Coefficients } \\
\cline { 2 - 7 } & (Constant) & 7,762 & Std. Error & Beta & T & Sig. \\
\hline AQ & 0,181 & 0,069 & & 0,197 & 2,859 & 0,005 \\
& SE & 0,404 & 0,109 & 0,421 & 3,696 & 0,010 \\
NACH & 0,206 & 0,098 & 0,238 & 2,104 & 0,000 \\
& & & & &
\end{tabular}

a. Dependent Variable: $I B$ 
Berdasarkan Tabel 9 variabel adversity quotient memiliki nilai $t_{\text {hitung }}$ sebesar 2,619. Nilai $t_{\text {hitung }}$ kemudian dibandingkan dengan nilai $t_{\text {tabee }}$, yang dicari pada $\alpha=5 \%: 2=2,5 \%$ (uji 2 sisi) dengan derajat kebebasan (df) $n-k-1$ atau 102-3-1, $n$ adalah jumlah sampel dan $\mathrm{k}$ adalah jumlah variabel bebas. Berdasarkan perhitungan tersebut, didapat $t_{\text {tabel }}$ sebesar 1,984 dengan demikian $t_{\text {hitung }}>t_{\text {tabel. }}$. Signifikansi pada variabel adversity quotient sebesar 0,010 dan dengan demikian lebih kecil dari 0,05. Kesimpulan yang dapat diambil adalah $H_{o}$ ditolak dan $H_{a}$ diterima. Dengan demikian adversity quotient memiliki pengaruh positif dan signifikan terhadap intensi berwirausaha.

Tabel 9 juga menunjukkan nilai $t_{\text {hitung }}$ untuk variabel self efficacy sebesar 3,696 serta nilai signifikansi sebesar 0,000. Hal tersebut menunjukkan bahwa $t_{\text {hitung }}>t_{\text {tabel }}$ dan nilai signifikansi lebih kecil dari 0,05 . Artinya, $H_{0}$ ditolak dan $H_{a}$ diterima. Dengan demikian, self-efficacy berpengaruh positif dan signifikan terhadap intensi berwirausaha. Variabel need for achievement menunjukkan nilai $t_{\text {hitung }}$ sebesar 2,104 dan nilai signifikansi 0,038 . Hal ini menunjukkan bahwa $t_{\text {hitung }}>t_{\text {tabel }}$ dan nilai signifikansi lebih kecil dari 0,05 . Artinya, $H_{0}$ ditolak dan $H_{a}$ diterima. Dengan demikian, need for achievement berpengaruh positif dan signifikan terhadap intensi berwirausaha.

Hasil selanjutnya adalah output F-test untuk mengetahui apakah secara simultan seluruh variabel bebas berpengaruh terhadap intensi berwirausaha dan hasilnya dapat dilihat pada Tabel 10.

Tabel 10

Hasil F-Test

\begin{tabular}{|c|c|c|c|c|c|c|}
\hline \multicolumn{7}{|c|}{$A N O V A^{b}$} \\
\hline & Model & $\begin{array}{l}\text { Sum of } \\
\text { Squares }\end{array}$ & $D f$ & $\begin{array}{l}\text { Mean } \\
\text { Square }\end{array}$ & $F$ & Sig. \\
\hline \multirow[t]{3}{*}{1} & Regression & 689,812 & 3 & 229,9372 & 28,018 & $0,000^{\mathrm{a}}$ \\
\hline & $\overline{R e s i d u a l}$ & 804,266 & 98 & 8,207 & & \\
\hline & Total & 1494,078 & 101 & & & \\
\hline
\end{tabular}

Pada Tabel $10, F_{\text {hitung }}$ yang diperoleh adalah sebesar 28,018. Nilai $F_{\text {hitung }}$ kemudian dibandingkan dengan nilai $F_{\text {tabel }}$, yang dicari dengan tingkat keyakinan $95 \%, \alpha=5 \%$, dengan $d f 1$ (jumlah variabel-1) atau 4$1=3$, dan $d f 2(n-k-1)$ atau 102-3-1=98. Berdasarkan perhitungan tersebut, didapat $F_{\text {tabel }}$ sebesar 2,69 dan dengan demikian $\mathrm{F}_{\text {hitung }}>\mathrm{F}_{\text {tabel }}$. Signifikasi pada uji $F$ dalam tabel adalah sebesar 0,000 yang lebih kecil dari 0,05 . Kesimpulan yang dapat diambil adalah variabel independen adversity quotient, self-efficacy dan need for achievement secara simultan berpengaruh positif terhadap intensi berwirausaha. Besarnya kontribusi seluruh variabel bebas terhadap intensi berwirausaha dapat dilihat dari Tabel 11.

Tabel 11

Hasil Uji Determinasi $\left(\boldsymbol{R}^{2}\right)$

\begin{tabular}{ccccc}
\hline \multicolumn{5}{c}{ Model Summary } \\
\hline Model & $R$ & $R$ Square & $\begin{array}{c}\text { Adjusted } R \\
\text { Square }\end{array}$ & $\begin{array}{c}\text { Std. Error of } \\
\text { the Estimate }\end{array}$ \\
\hline 1 & $0,679^{\mathrm{a}}$ & 0,462 & 0,445 & 2,865 \\
\hline
\end{tabular}

a. Predictors: (Constant), AQ, SE, NACH

Berdasarkan Tabel 11, nilai $R^{2}$ adalah sebesar 0,462. Dengan demikian, variabel adversity quotient, self-efficacy dan need for achievement secara simultan memiliki persentase sumbangan pengaruh terhadap variabel intensi berwirausaha sebesar $46,2 \%$.

\section{Diskusi dan Pembahasan}

Berdasarkan hasil uji hipotesis, dugaan awal yang menyebutkan bahwa rendahnya intensi berwirausaha mahasiswa adalah disebabkan karena tingkat adversity quotient yang rendah ternyata terbukti. Hasil ini sejalan dengan beberapa penelitian terdahulu seperti yang dilakukan oleh Wijaya (2007), Alfiyah (2012), serta Rahardjo dan Darmawan (2014).

Berdasarkan pengamatan yang dilakukan peneliti, rendahnya adversity quotient pada mahasiswa tata busana saat ini disebabkan oleh beberapa faktor. Pertama, mayoritas mahasiswa yang diteliti berasal dari latar belakang keluarga yang relatif mapan dari sisi ekonomi, sehingga mereka memiliki kemudahan akses untuk memenuhi berbagai keinginan dan kebutuhannya. Kondisi ini secara tidak langsung "memanjakan" mereka sehinggga cenderung tidak terlatih untuk menghadapi kesulitan. Disisi lain, mereka paham bahwa menjadi pengusaha akan menemuni banyak kesulitan dan tantangan sehingga mereka cenderung tidak begitu tertarik pada profesi tersebut.

Kedua, rendahnya adversity quotient mahasiswa disebabkan oleh kehidupan sosial mereka dan kondisi lingkungan yang serba instan serta cenderung materialistis. Kondisi ini membuat mahasiswa ingin segera meraih kesuksesan atau ingin segera kaya dengan perjuangan seminimal mungkin. Kontradiksi inilah yang menurunkan semangat dan keinginan mereka untuk menjadi pengusaha yang tentu akan memerlukan perjuangan keras untuk mencapai kesuksesan.

Hasil berikutnya dari uji hipotesis juga membuktikan bahwa rendahnya self-efficacy berpengaruh terhadap kurangnya minat mahasiswa menjadi pengusaha. Hasil ini konsisten dengan beberapa penelitian 
yang dilakukan oleh Gerhardt dan Kickul (2007), Flavius (2010), serta Handaru et al, (2013). Fakta ini dapat ditinjau dari sisi pengetahuan dan keterampilan mahasiswa yang tidak optimal sehingga menurunkan kepercayaan diri mereka untuk membuka bisnis baru. Dari pengamatan terhadap kurikulum dapat diketahui bahwa rancangan kurikulum yang diterapkan bagi mahasiswa kurang mengoptimalkan pengembangan keterampilan dari sisi perancangan atau desain busana. Kompleksitas kurikulum juga ditambah dengan kurangnya pemahaman mahasiswa mengenai industri fashion di tingkat lokal, nasional, maupun internasional. Kondisi ini membuat mahasiswa menjadi kurang percaya diri untuk terjun kedalam bisnis/industri fashion seperti harapan semula.

Hasil ketiga adalah fakta bahwa intensi berwirausaha mahasiswa yang rendah disebabkan oleh need for achievement yang rendah pula. Temuan ini sejalan dengan beberapa studi lain seperti yang dilakukan oleh Setyawan (2009) serta Kalyani dan Kumar, (2011). Pengamatan yang dilakukan terhadap mahasiswa yang dijadikan sampel mengungkapkan bahwa mayoritas mahasiswa masih belum fokus pada upaya untuk mencapai prestasi tinggi. Jika dilihat dari aspek prestasi akademik, mayoritas mahasiswa memiliki indeks prestasi akademik yang biasa saja. Seperti halnya mahasiswa pada umumnya, kebanyakan sampel dalam penelitian ini juga masih terlihat kebingungan untuk menentukan arah dan prioritas tujuan karir mereka. Dengan kata lain mereka masih senang "bermain-main" dan kurang serius dalam mempersiapkan karir.

Kehidupan mahasiswa di kampus yang cenderung "menyenangkan" dan "santai" menyebabkan dorongan berprestasi menjadi rendah. Kondisi ini akhirnya juga berpengaruh terhadap pilihan karir mereka, termasuk ketika dihubungkan dengan minat untuk membuka bisnis sendiri. Dari hasil uji hipotesis juga diketahui bahwa secara simultan adversity quotient, self-efficacy, dan need for achievement dapat membentuk entrepreneurrial intention mahasiswa sebesar $46,2 \%$. Informasi ini menegaskan bahwa masih terdapat faktor lain selain ketiga variabel bebas di atas yang perlu dimasukkan untuk memberikan gambaran yang lebih utuh dan komprehensif mengenai pembentukan intensi berwirausaha terutama di kalangan mahasiswa.

\section{Simpulan dan Implikasi}

Berdasarkan analisis dan hasil pengujian hipotesis yang telah dilakukan sebelumnya, dapat diambil beberapa kesimpulan sebagai berikut:
1. Tingkat adversity quotient, self-efficacy, need for achievement serta entrepreneurial intention mahasiswa program tata busana adalah rendah.

2. Adversity quotient memiliki pengaruh positif terhadap intensi berwirausaha mahasiswa.

3. Self-efficacy memiliki pengaruh positif terhadap intensi berwirausaha mahasiswa.

4. Need for achievement memiliki pengaruh positif terhadap intensi berwirausaha mahasiswa.

5. Secara simultan adversity quotient, self-efficacy dan need for achievement memiliki pengaruh positif pada pembentukan intensi berwirausaha mahasiswa.

Berdasarkan hasil penelitian yang telah disajikan sebelumnya, terdapat beberapa implikasi yang perlu diperhatikan oleh beberapa pihak yang terkait dengan studi ini. Pertama, pihak program studi perlu melakukan tinjauan ulang atau revisi terhadap kurikulum yang diterapkan kepada mahasiswa. Peninjauan ini dapat berupa penambahan porsi praktek perancangan/ desain sejak awal perkuliahan untuk mengoptimalkan kompetensi mereka, termasuk di dalamnya meningkatkan atmosfir berwirausaha di bidang fashion design kepada seluruh mahasiswa. Mahasiswa juga perlu mendapatkan gambaran nyata mengenai kondisi industri fashion design dengan memperbanyak interaksinya dengan pihak industri di luar kampus. Kegiatan seperti ini dapat difasilitasi oleh program studi.

Kedua, mahasiswa sebagai calon entrepreneur perlu memperkaya dirinya sendiri dengan softskill dan hardskill yang mendorong semangat untuk berwirausaha. Mahasiswa dituntut untuk belajar mandiri dan mampu berinisiatif menggali potensi dirinya masingmasing terkait dengan softskill dan hardskill tersebut. Untuk penelitian selanjutnya, disarankan untuk memasukkan beberapa variabel lain di luar penelitian ini untuk mendapatkan gambaran yang lebih utuh mengenai pembentukan intensi berwirausaha, seperti kondisi ekonomi, gender, latar belakang orang tua, dan budaya.

\section{Daftar Referensi}

Alfiyah, N. (2012). Hubungan adversity quotient dengan prestasi belajar matematika pada siswa kelas ix smp negeri 1 tempel jurusan psikologi pendidikan dan bimbingan fakultas ilmu pendidikan universitas negeri Yogyakarta. Diunduh Maret 2014 dari http://eprints.uny.ac.id/9771/2/ BAB\%202\%20-\%200710424409 2.pdf.

Antoncic, B., Scarlat, C. \& Erzetic, B. H. (2005). The quality of entrepreneurship education and the intention to continue education: Slovenia and 
Romania. Managing Global Transitions, 3(2), 197-212.

Bogan, V. \& Darity, W. (2008). Culture and entrepreneurship? African American and immigrant selfemployment in the United States. The Journal of Socio-Economics, 37, 1999-2019.

Constantin, D. L., Goschin, Z., \& Dragusin, M. (2008). Ethnic entrepreneurship as an integrating factor in civil society and a gate to religious tolerance: a spotlight on Turkish entrepreneurs in Romania. Journal for the Study of Religions and Ideologies, 7(20), 49-79.

Flavius, T. E. (2010). Gender, entrepreneurial selfefficacy, and entrepreneurial attitude orientations: The case of the Caribbean. International Business \& Economics Research Journal, 9(13), $17-31$.

Fuad, N. \& Bohari, A. M. (2011). Malay women entrepreneurs in the small and medium sized ictrelated business: A study on need for achievement. International Journal of Business and Social Science, 2(13), 1-7.

Gerhardt, M. W. \& Kickul, J. R. (2007). The role of cognitive style and risk preference on entrepreneurial self-efficacy and entrepreneurial intentions. Journal of Leadership and Organizational Studies, 13(4), 87-104.

Ghozali, I. (2005). Aplikasi analisis multivariate dengan program IBM spss. Semarang: Penerbit Universitas Diponegoro.

Hair, J. F., Black, W. C., Babin, B. J., Anderson, R. E., \& Tatham, R. L. (2006). Multivariate data analysis. New Jersey: Prentice Hall

Handaru, A. W., Parimita, W., Achmad, A., \& Nandiswara, C. (2014). Pengaruh sikap, norma subjektif, dan efikasi diri terhadap intensi berwirausaha mahasiswa magister management (kajian empiris pada sebuah universitas negeri). Jurnal Paramadina, 11(2), 1046-1061.

Handaru, A. W., Parimita, W., \& Subekti, W. (2013). Entrepreneurial self-efficacy, ethnicity, gender and educational background: Evidence from the kuningan international trade centre, Jakarta, Indonesia. In F. L., Gaol, S. Kadry, M. Taylor, \& S. L. Pak, Recent Trends in Social and Behaviour Sciences, pp. 113-118. UK: CRC Press, Taylor \& Francis Group.

Handaru, A. W., Waspodo, A., \& Carolina, C. (2013). Motivational factors, entrepreneurship, gender, and parental background: evidence from the tailor's guild at sunan giri traditional market, Jakarta, Indonesia. China-USA Business Review, 12 (6), 627-635.
Hmieleski, K. M., \& Baron, R. A. (2008). When does entrepreneurial self-efficacy enhance versus reduce firm performance? Strategic Entrepreneurship Journal, 2, 57 -72.

Ismail, M., Khalid, S. A., Othman, M., Jusoff, K., Mohammed, K. M., \& Shekh, R.Z. (2009). Entrepreneurial intention among Malaysian undergraduates. International Journal of Business and Management, 4(10), 54-60.

Kalyani, B. \& Kumar D. M. (2011). Motivational factors, entrepreneurship, and education: Study with reference to women in sme's. Far East Journal of Psychology and Business, 3(3), 1435.

Kuncoro, M. (2009). Metode riset untuk bisnis dan ekonomi. Jakarta: Erlangga

Linan, F. (2008). Skill and value perceptions: How do they affect entrepreneurial intentions? International Entrepreneur Management Journal, 4, 257-272.

Linan, F. \& Chen, Y. W. (2006). Testing the entrepreneurial intention model on a two-country sample. Diunduh 7 Maret 2014 dari http://www. recercat.net/bitstream/handle/2072/2213/?sequence $=1$.

Linan, F., \& Santos, F. J. (2007). Does social capital affect entrepreneurial intentions? International Advanced Economy Research, 13, 443-453.

Maysami, R. C. \& Ziemnowicz, C. (2007). Ethnicity, gender and entrepreneurial tendencies: the $\mathrm{Si}-$ ngapore perspective. The Copenhagen Journal of Asian Studies, 25, 1-15.

Muofhe, N. J. \& Du Toit, W. F. (2011). Entrepreneurial education's and entrepreneurial role models' influence on career choice. Journal of $\mathrm{Hu}$ man Resource Management, 9(1), 1-15.

Rahardjo, P. \& Darmawan, A. (2014). Hubungan kemandirian dan motivasi berpretasi pada intensi berwirausaha pada mahasiswa. Diunduh Maret 2014 dari http://jurnal.ump.ac.id/index.php/EKO NOMI/article/view/267.

Rahman, K. M. (2011). Entrepreneur needs and achievement of descendant latin-japanesse entrepreneurs in Japan. International Journal of Entrepreneurship, 15, 99-119.

Raposo, M. \& Paco, A. (2011). Entrepreneurship education: Relationship between education and entrepreneurial activity. Psicothema, 23(3), 453457

Scheers, L. V. (2010). The role of ethnicity and culture in developing entrepreneurs in South Africa. Problems and Perspectives in Management, 8 (4), 20-28. 
Setyawan, B. N. (2009). Analisis perbedaan kebutuhan akan prestasi, afiliasi, otonomi, dominasi pada karyawan wanita dan entrepreneur wanita serta faktor yang mempengaruhi. Diunduh Mei 2014 dari http://thesis.umy.ac.id/datapublik/t1 2639.pdf.

Srimulyani, A.V. (2013). Pengaruh kecerdasan adversitas, internal locus of control, dan kematangan karir terhadap intensi berwirausaha pada mahasiswa bekerja. Widya Warta, 1, 96-110.

Sugiyono. (2013). Metode penelitian manajemen. Bandung: Alfabeta.

Sukmana, U. D. (2008). Peran pendidikan kewirausahaan dalam menumbuhkan motivasi (studi tentang pengaruh pendidikan kewirausahaan terhadap motivasi wirausaha mahasiswa universitas kuningan). Equilibrium, 4(8), 1-23.

Vemmy, S. C. (2013). Faktor-faktor yang mempengaruhi intensi berwirausaha siswa smk di Yogyakarta. Jurnal Pendidikan Vokasi, 2(1), 117-125.

Wijaya, T. (2007). Hubungan adversity intelligence dengan intensi berwirausaha studi empiris pada siswa smkn 7 Yogyakarta. Jurnal Manajemen dan Kewirausahaan, 9(2), 107-116.

Zaki, A., Fadzely, M., \& Ahmed, E. M. (2006). Study of motivation in business start-ups among Malay entrepreneurs. International Business \& Economics Research Journal, 5(2), 103-112. 